\title{
Spatio-temporal development of vegetation die-off in a submerging coastal marsh
}

\author{
Lennert Schepers, ${ }^{\boldsymbol{*}}$ Matthew Kirwan, ${ }^{\mathbf{2}}$ Glenn Guntenspergen, ${ }^{\mathbf{3}}$ Stijn Temmerman ${ }^{\mathbf{1}}$ \\ ${ }^{1}$ Ecosystem Management Research Group, Department of Biology, University of Antwerp, Wilrijk, Belgium \\ ${ }^{2}$ Virginia Institute of Marine Science, College of William and Mary, Gloucester Point, Virginia \\ ${ }^{3}$ Patuxent Wildlife Research Center, U.S. Geological Survey, Beltsville, Maryland
}

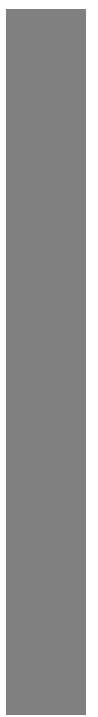

\begin{abstract}
In several places around the world, coastal marsh vegetation is converting to open water through the formation of pools. This is concerning, as vegetation die-off is expected to reduce the marshes' capacity to adapt to sea level rise by vegetation-induced sediment accretion. Quantitative analyses of the spatial and temporal development of marsh vegetation die-off are scarce, although these are needed to understand the biogeomorphic feedback effects of vegetation die-off on flow, erosion, and sedimentation. In this study, we quantified the spatial and temporal development of marsh vegetation die-off with aerial images from 1938 to 2010 in a submerging coastal marsh along the Blackwater River (Maryland, U.S.A). Our results indicate that die-off begins with conversion of marsh vegetation into bare open water pools that are relatively far ( $>75 \mathrm{~m}$ ) from tidal channels. As vegetation die-off continues, pools expand, and new pools emerge at shorter and shorter distances from channels. Consequently larger pools are found at larger distances from the channels. Our results suggest that the size of the pools and possibly the connection of pools with the tidal channel system have important bio-geomorphic implications and aggravate marsh deterioration. Moreover, we found that the temporal development of vegetation die-off in moderately degraded marshes is similar as the spatial die-off development along a present-day gradient, which indicates that the contemporary die-off gradient might be considered a chronosequence that offers a unique opportunity to study vegetation die-off processes.
\end{abstract}

Coastal marshes are wetlands with important ecosystem functions such as coastal protection (Temmerman et al. 2013; Möller et al. 2014; Temmerman and Kirwan 2015), improving water quality and recreation (Barbier et al. 2011), with estimated total monetary values ranging from 2,000 to $215,000 \$ \mathrm{ha}^{-1} \mathrm{yr}^{-1}$ (Russi et al. 2013). These functions may disappear when coastal marsh vegetation dies off and marshes convert to bare intertidal flats, pools, or open water, as is observed in different places around the world (Boston 1983; Day et al. 2000; Kearney et al. 2002; Perillo and Iribarne 2003; Kirwan and Megonigal 2013). Vegetation dieback and pool formation have been proposed as an early indicator of a marsh that is failing to survive sea level rise (e.g., Kearney et al., 1988; Nyman et al., 1993) and pool enlargement is a primary component of wetland loss in submerging marshes typical, for example, of the Mississippi Delta, Chesapeake Bay and Venice lagoon (Stevenson et al.

\footnotetext{
*Correspondence: lennert.schepers@uantwerpen.be
}

1985; Wells and Coleman 1987; Kearney et al. 1988; Nyman et al. 1993; Penland et al. 2000; Carniello et al. 2009).

Marshes are known to have two contrasting ecosystem states (Fagherazzi et al. 2006; Marani et al. 2010; Wang and Temmerman 2013): (i) an elevated, vegetated marsh state and (ii) a low, unvegetated tidal flat or shallow open water (pool) state. In the vegetated marsh state, several biogeomorphic feedback mechanisms allow the marsh platform elevation to keep up with sea level rise. As marsh vegetation is flooded for longer periods of time and more frequently, the vegetation will trap and accumulate more suspended sediment, resulting in the build-up of the marsh surface that may be in balance with sea level rise (Pethick 1981; Allen 1990; French 1993; Vandenbruwaene et al. 2011a). Aboveground and belowground plant production increases elevation by (i) reduction of tidal flow and enhanced suspended sediment deposition (Mudd et al. 2010; Baustian et al. 2012; Temmerman et al. 2012a) and (ii) organic matter accumulation that directly contributes to elevation increase (Nyman et al. 2006; Kirwan and Guntenspergen 2012). For some marsh species such as Spartina alterniflora and Schoenoplectus 
americanus, maximum productivity occurs at intermediate or low elevations within the intertidal zone, so that increased flooding of high marshes will enhance productivity and accretion (Morris et al. 2002; Kirwan and Guntenspergen 2015). Consistent with these observations, a recent metaanalysis suggests that accretion rates could more than double during the transition from infrequently flooded, high elevation marshes to frequently flooded, low elevation marshes (Kirwan et al. 2016). These bio-geomorphic feedbacks between tidal inundation, vegetation productivity, and surface elevation change provide vegetated marshes a certain ability to keep up with rising sea level (Kirwan et al. 2010; Fagherazzi et al. 2012; Mariotti and Carr 2014).

However, marshes can only keep up with sea level rise to a certain extent. When excessive flooding becomes harmful to plant growth, plant productivity and vegetation-induced accretion processes decline (Nyman et al. 1993; Morris et al. 2002; Leonard and Croft 2006). When reduced accretion rates get lower than the rate of sea level rise, this results in an increasing inundation stress, which may ultimately lead to vegetation die-off and the formation of shallow water pools without vegetation. Plant mortality may be accompanied by loss of elevation due to collapse of the root structure or decomposition and disintegration of soil organic matter, resulting in die-off areas that are too low for vegetation to reestablish (DeLaune and Pezeshki 1994; van Huissteden and van de Plassche 1998; Day et al. 2011).

The origin, causes, and evolution of tidal marsh die-off have been an important area of study. Initial vegetation dieoff usually starts as isolated areas in the interior marsh (DeLaune et al. 1994; Morton et al. 2003) by excessive flooding and waterlogging (Boston 1983; Mendelssohn and McKee 1988; Nyman et al. 1993; DeLaune et al. 1994; Day et al. 2011), salt stress (Delaune and Pezeshki, 1994), herbivory (Stevenson et al. 1985; Silliman 2005; Kirwan et al. 2008; Smith 2009; Holdredge et al. 2009), deposition of tidal litter (Pethick 1974; Boston 1983), physical disturbances, or other reasons that may not be always clear (see e.g., Alber et al. (2008) for an overview of rapid dieback mechanisms). The loss of vegetation may decrease the physical deposition of suspended sediments or even provoke erosion (Baustian et al. 2012; Temmerman et al. 2012a), leading to the formation of depressions or pools with weak soil strength that may inhibit the re-establishment of vegetation (Day et al. 2011). The enlargement of pools is a poorly understood phenomena, but might be caused by rotational slumping (Stevenson et al. 1985), failure of unstable marsh scarps (Day et al. 2011), surficial flooding of the adjacent marsh surface and consequent vegetation die-off (Wilson et al. 2009), or by decomposition and decay of the upper soil layer, leading to pool enlargement (Redfield 1972; van Huissteden and van de Plassche 1998). Also wind-generated wave erosion may expand the pools (Stevenson et al. 1985; Perillo et al. 1996; Morton et al. 2003; Mariotti and Fagherazzi 2013).
Neighboring pools may merge to form larger pools (Yapp et al. 1917; Redfield 1972; Kearney et al. 1988; Wilson et al. 2009). This process can start by subsurface connections between adjacent pools (van Huissteden and van de Plassche 1998; Wilson et al. 2009). Pools can also get connected to the tidal channel network by headward erosion of channels into pools (Redfield 1972; Kearney et al. 1988; Perillo et al. 1996). The pools can become subsequently drained, which may induce (partial) revegetation of the pools and rapid sediment accretion (Redfield 1972; Perillo et al. 1996; van Huissteden and van de Plassche 1998; Wilson et al. 2009, 2010, 2014; Millette et al. 2010). In this way, pools can also become smaller in size, break apart, or completely disappear (Redfield 1972; Wilson et al. 2009, 2014). Wilson et al. (2009) observed several pools and their development over time in the Webhannet Salt Marsh (Maine, U.S.A.), concluding that pools are highly dynamic, with simultaneous contraction and expansion of pools and most of the pools decreasing in size during the time period studied (19622003). However, in other marsh areas such as in the Nanticoke and Blackwater estuaries (Maryland, U.S.A.) and the Mississippi delta (Louisiana, U.S.A.) pools enlarge until they are big enough for wind-generated wave erosion of the pool bottom and edges (Stevenson et al. 1985; Kearney et al. 1988; Mariotti and Fagherazzi 2013) and die-off gradually continues over time to mostly open water areas with a few remnant islands of marsh that eventually disappear (Morton et al. 2003).

Detailed quantitative studies of spatio-temporal die-off patterns at a geomorphic relevant scale $(<1 \mathrm{~km})$ are largely lacking, and this hinders the quantitative study of the feedbacks of vegetation die-off patterns on flow and sedimentation (D'Alpaos et al. 2007; Kirwan and Murray 2007; Temmerman et al. 2012a,b). In this study, we quantify the spatio-temporal development of vegetation die-off in a submerging marsh area of the Chesapeake Bay (Blackwater marshes, Maryland, U.S.A.) by analyzing aerial images from 1938 to 2010. We test if changes in die-off patterns through time are similar to dieoff patterns occurring along an apparent present-day spatial gradient and hypothesize that the distance from tidal channels is a key determining factor explaining the spatial pattern of pool initiation and development. More specifically, we test if initial pool formation and consequent enlargement occurs randomly relative to the tidal channels, or preferentially at certain distances from channels. Finally, we formulate possible implications of the observed die-off patterns for biogeomorphic feedback mechanisms.

\section{Methods}

Study area

The study area is located along the Blackwater River (Maryland, U.S.A.) that discharges into the Fishing Bay $\left(38^{\circ} 24^{\prime} \mathrm{N}, 76^{\circ} 40^{\prime} \mathrm{W}\right.$, Fig. 1), which is a tributary embayment 


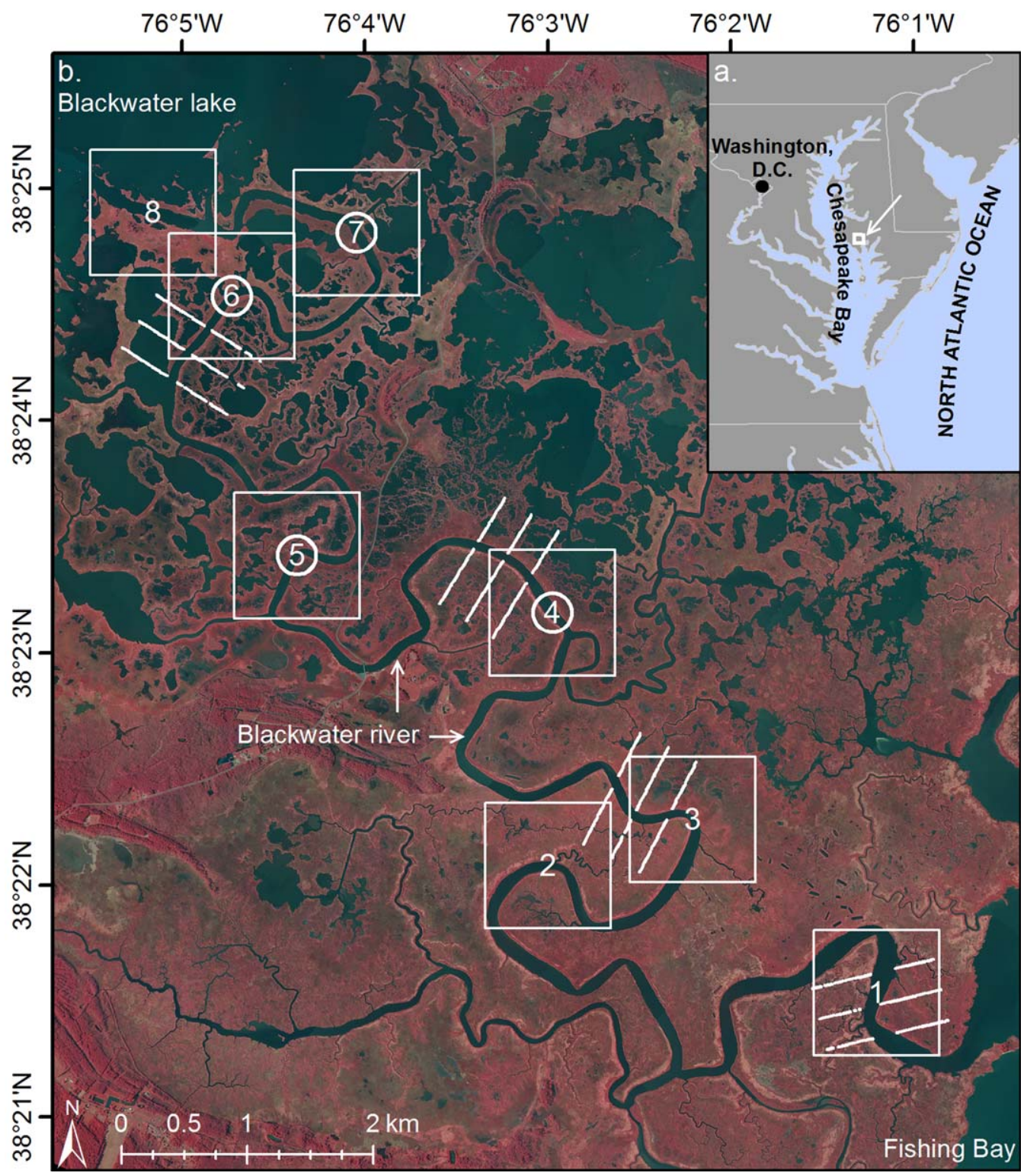

Fig. 1. (a) Position of the Blackwater marshes (white arrow) along the Chesapeake Bay, Maryland, U.S.A. (b) Black-white (False color image online: Near Infrared, Red, and Green band) of the Blackwater marshes in 2010. Dark areas are water areas, brighter (online: reddish) colors are vegetation. The numbered squares (1-8) represent the areas used in the spatial image analyses. Squares with encircled numbers (4-7) are also used in the temporal image analyses. White lines consist of ground validation points for the 2010 image classification. [Color figure can be viewed at wileyonlinelibrary. com]

of the larger Chesapeake Bay. The upstream marshes are part of the Blackwater National Wildlife Refuge, the downstream marshes are situated in the Fishing Bay Wildlife Management Area. The estuary is micro-tidal with the spring tidal range varying from over $1.0 \mathrm{~m}$ at the Fishing Bay (in the southeast corner of Fig. 1b) to less than $0.2 \mathrm{~m}$ at the open water area (indicated as "Blackwater lake" in the northwest corner of Fig. 1b) (Ganju et al., 2013). However, episodic meteorological tides may exceed $1.0 \mathrm{~m}$ at the Chesapeake Bay (Wang and Elliott 1978; Stevenson et al. 1985). The marshes are characterized by mesohaline marsh vegetation: Spartina cynosuroides is dominant on natural levees next to the river and the bigger tidal channels. Intermediate elevations are dominated by different mixtures of Spartina alterniflora, Spartina patens, and Distichlis spicata, and the lowest areas are dominated by Schoenoplectus americanus.

Since the 1930s, more than 2,000 ha of marshland or $51 \%$ of the Blackwater National Wildlife Refuge marshes have been lost and converted to open water (Stevenson et al. 1985; Scott et al. 2009; Cahoon et al. 2010), resulting in an 
Table 1. Overview of used imagery

\begin{tabular}{llcll}
\hline Date & \multicolumn{1}{c}{ Type } & Resolution $(\mathbf{m})$ & \multicolumn{1}{c}{ Source } & Digitization \\
\hline 1938 & Black and white & 0.86 & Scott et al. (2009) & Manual \\
1981 & Color Infrared & 1.55 & USGS Earthexplorer & Manual \\
2010 & Visible + near infrared (4 bands) & 0.30 & Blackwater National Wildlife Refuge & Classification \\
\hline
\end{tabular}

upstream gradient of increasing vegetation die-off from fairly intact marshes closest to the Fishing Bay up to the vast open shallow water Lake Blackwater that was still partly vegetated until the 1930s. As marsh vegetation died, it was replaced by subtidal pools that are clearly distinguishable from aerial pictures (Fig. 1b). The historical marsh accretion rate (on average 1.7-3.6 $\mathrm{mm} \mathrm{yr}^{-1}$ (Stevenson et al. 1985)) is lower than the local relative sea level rise (currently $3.72 \mathrm{~mm} \mathrm{yr}^{-1}$ nearby in Cambridge, MD, (NOAA station 8571892, http://tidesandcurrents.noaa.gov/sltrends, 2/23/2016)). Marsh loss at the Blackwater marshes has, besides submergence by sea level rise, also been attributed to vegetation disturbance by rodents (muskrats (Ondatra zibethicus) and invasive nutria (Myocastor coypus)) and subsequent open-water expansion (Stevenson et al. 1985; Kendrot 2011).

\section{Aerial images}

Aerial photographs were acquired for the historical analyses for 1938, 1981, and 2010 (Table 1) and were converted into maps delineating marsh vegetation, pools, and tidal channels. We obtained 1938 imagery (black and white) that was scanned and georeferenced (Scott et al. 2009). Scott et al. (2009) also digitized the extent of the wetland vegetation and water areas within the Blackwater National Wildlife Refuge area, that is, the more upstream marshes. We checked and adjusted this layer and extended it to the wetlands of the whole study area (Fig. 1). Upland areas and anthropogenic areas (roads, houses, wharfs) were excluded from the analysis. The 1981 image (infrared) was georeferenced (RMS: $5.4 \mathrm{~m}$ ). A supervised classification of the 1981 image was unsuccessful in discriminating vegetation and water areas, but we could clearly differentiate these two classes visually so we digitized the 1981 image manually. All manual digitization was done at a scale of 1:2,500 using a conservative interpretation of die-off areas: only larger $\left(>50 \mathrm{~m}^{2}\right)$ areas that were very likely ponds/water were characterized as such. Therefore, marsh die-off by pool formation might be slightly underestimated.

The 2010 imagery (visible light and near infrared) was classified with a supervised maximum likelihood classification to distinguish between vegetation and water areas. In the summer of 2014 , ground validation points $(n=1022$, see Fig. 1b) were collected every $10 \mathrm{~m}$ along transects crossing the Blackwater River and were used to validate the classification. The accuracy of the classification was very high (0.97), meaning that $97 \%$ of our ground control points were classified correctly. If we account for the chance of randomly assigning a value to a class, 91\% of our points were classified correctly (Kappa: 0.91), still a very good result. All images were resampled to the coarsest resolution of $1.55 \mathrm{~m}$ with majority resampling in ArcGIS. To make the 2010 classification comparable to the manual delineations on the 1981 and 1937 images (where only pools or vegetated patches where mapped when they were $>50 \mathrm{~m}^{2}$ ), individual areas smaller than $50 \mathrm{~m}^{2}$ were removed and replaced by its surrounding class. In this step, we used the 4-connected neighborhood to evaluate connectivity between cells to delineate individual areas. As a final step, the Blackwater River and the main tidal channels were classified separately from the pools. The tidal channels are defined as elongated water stretches (length at least two times larger than width) that are directly connected to the river.

\section{Spatial and temporal analysis}

Within the study area we selected discrete working areas to facilitate comparisons across the die-off gradient. We created a point every $2000 \mathrm{~m}$ along the centerline of the Blackwater River, from its mouth in the Fishing Bay in the SE up to the open water area in the NW, that is, 13 points in total. Two points were excluded because they were situated within $500 \mathrm{~m}$ of upland areas. The size of the square working areas was selected based on two aspects: (i) the change in proportion of water of the working area as the window size (i.e., size of the square working areas) increases and (ii) the overlap of working areas. The proportion of water was defined as the ratio of water pixels to the total amount of pixels within a working area. We centered our working areas around the 11 retained points. As we expand the window size beyond the river banks, the proportion of water drops as we encounter more vegetated marshes. When the window size reaches $1 \mathrm{~km}^{2}$, the proportion of water has stabilized for most working areas. For larger window sizes, the chance of overlap between adjacent working areas becomes high. Hence an appropriate window size for our analysis was chosen at $1 \mathrm{~km}^{2}$ (Fig. 2).

Three points were excluded at this stage as they had very similar vegetation cover (see Fig. 2) and significant overlap. Historical aerial imagery for all time steps was available for area 4 to area 7 (see Fig, 1, Table 1), and hence, these areas were used for the temporal analyses. 


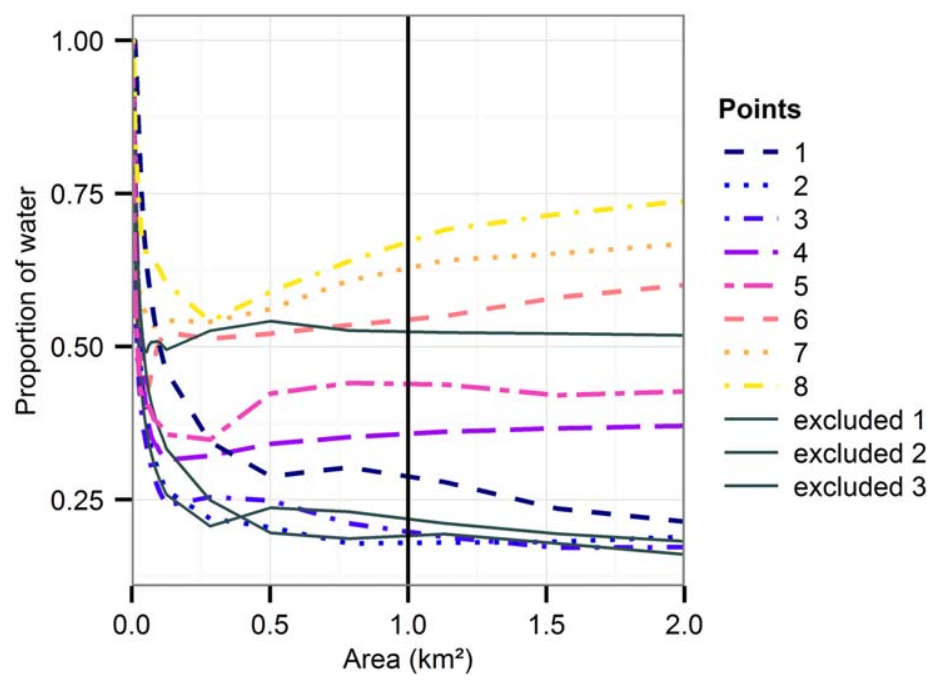

Fig. 2. Proportions of marsh occupied by water ( $Y$-axis) as a function of increasing size of the working areas ( $X$-axis). Dashed lines correspond to areas in Fig. 1. Solid lines indicate the three excluded areas. The vertical line marks the size of the working areas used in this study $\left(1 \mathrm{~km}^{2}\right)$. [Color figure can be viewed at wileyonlinelibrary.com]

\section{Die-off proportion}

As a first measure to see if the temporal evolution and apparent spatial gradient of vegetation die-off are similar, we defined the proportion of vegetation die-off (pools) as the ratio of pool pixels to the total of pool and vegetated marsh pixels for each working area. River pixels and tidal channel pixels were excluded as these are natural features of a marsh system and are not formed by vegetation die-off, while pools are considered the result of marsh vegetation die-off.

Relations between die-off percentage and distance from channels

We determined the distance of each pixel to the Blackwater River by an Euclidean distance calculation. We divided the distances in $5 \mathrm{~m}$ bins and calculated within each distance bin the proportion of pools (the same method as above). Distances were visualized until a bin represents less than $0.5 \%$ of the total amount of pixels in the working area (pool + marsh pixels). By doing so, larger distances that represent only a very small percentage of the total area were left out of the analyses.

\section{Relations between pool size and distance from channels}

An important measure regarding pool enlargement is the size of the pools and how the size evolves in time. As pools are often connected by channel-like patterns which do not allow for individual pool delineation and the marsh landscape is inherently intersected by tidal channels, conventional spatial pattern analyses based on identification of individual patches (McGarigal et al. 2012; Kéfi et al. 2014) are not possible. Therefore, we used fetch length as a proxy for pool size. The fetch or fetch length of a pool is defined as the length of a line that covers a continuous water surface, from one side of the pool to the other. For each pool pixel, we determined the fetch length oriented along the cardinal and intercardinal directions (N-S, E-W, NW-SE; NE-SW). The mean fetch was calculated from these four fetch lengths. We analyzed the fetch length for different distance classes to the river (bins), identically as the method used above.

All analyses were performed with ArcGIS (ArcGIS 10.3, ESRI) and R (R Core Team 2016).

\section{Results}

\section{Evolution of die-off proportion}

Figures 3 and 4 represent the proportion of pools compared to the total amount of pool and marsh pixels, excluding tidal channels and the river channel, for the time steps and all spatial areas, respectively. We observe an increase in pool cover for all time steps and all the areas in the temporal analysis, with up to $21 \%$ of marsh converted to pools in 29 yr (Fig. 3: area 6, 1981 to 2010). This indicates that the dieoff is an ongoing, active process. The spatial analysis shows the same trend as the temporal change: a very small percentage of pool cover at area 1 increases gradually along the Blackwater River, up to $62 \%$ of pools close to Lake Blackwater in area 8 (Fig. 4). It should be noted, however, that there are no intact marshes ( $<10 \%$ vegetation die-off) in the temporal analysis.

\section{Relations between die-off percentage and distance from channels}

The proportion of pools for different distances to the Blackwater River are presented in Fig. 5 for different time steps and for all the areas in 2010 in Fig. 6. In 1938, the pool proportions were limited and there were almost no pools within $100 \mathrm{~m}$ from the river (see Fig. 5, yellow dash dot lines). Increasing numbers of pool pixels were situated at 

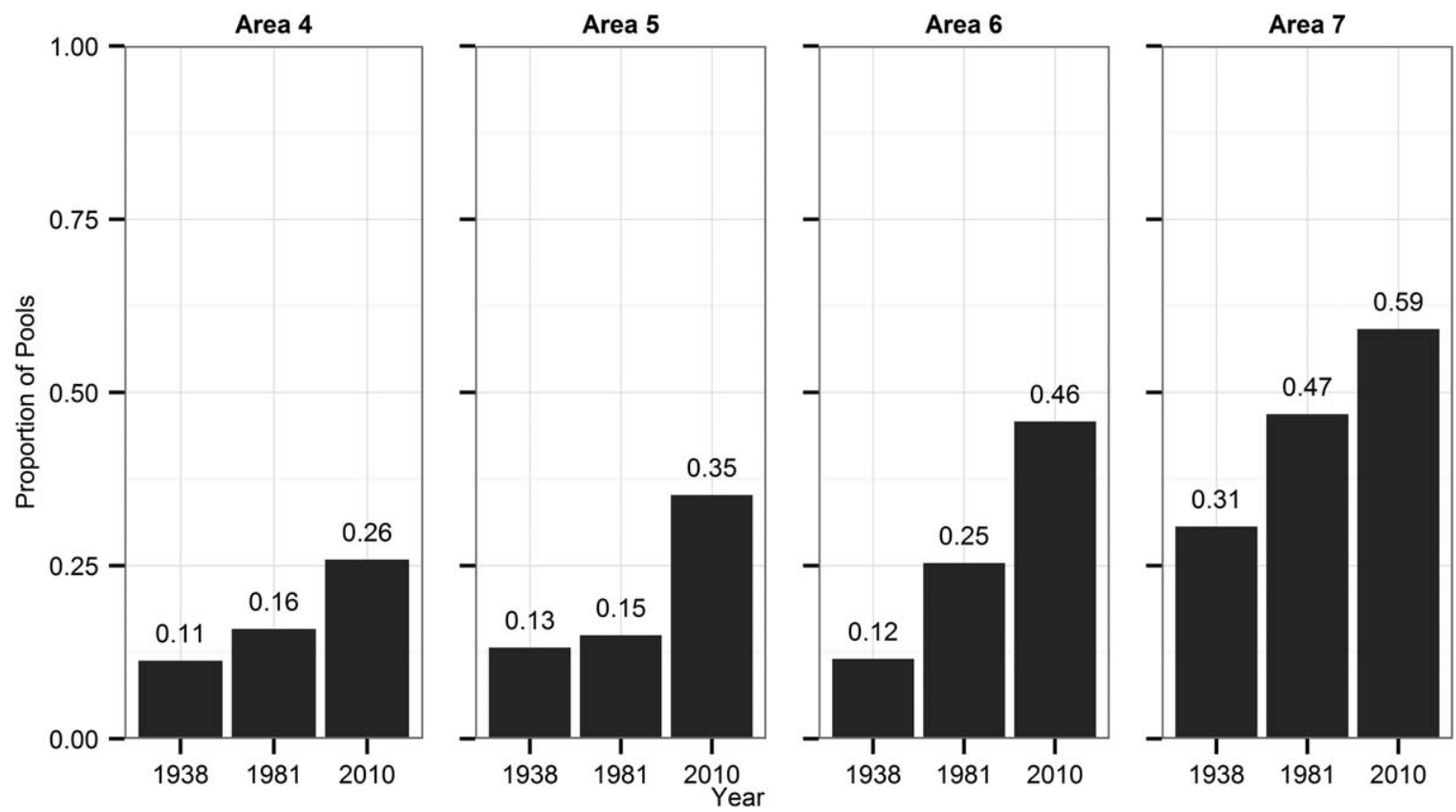

Fig. 3. Fraction of each working area occupied by unvegetated pools in 1938, 1981, and 2010. Pools represent areas of vegetation die-off and do not include tidal channels. Working areas 4-7 correspond to increasing distances up the Blackwater River toward Lake Blackwater.

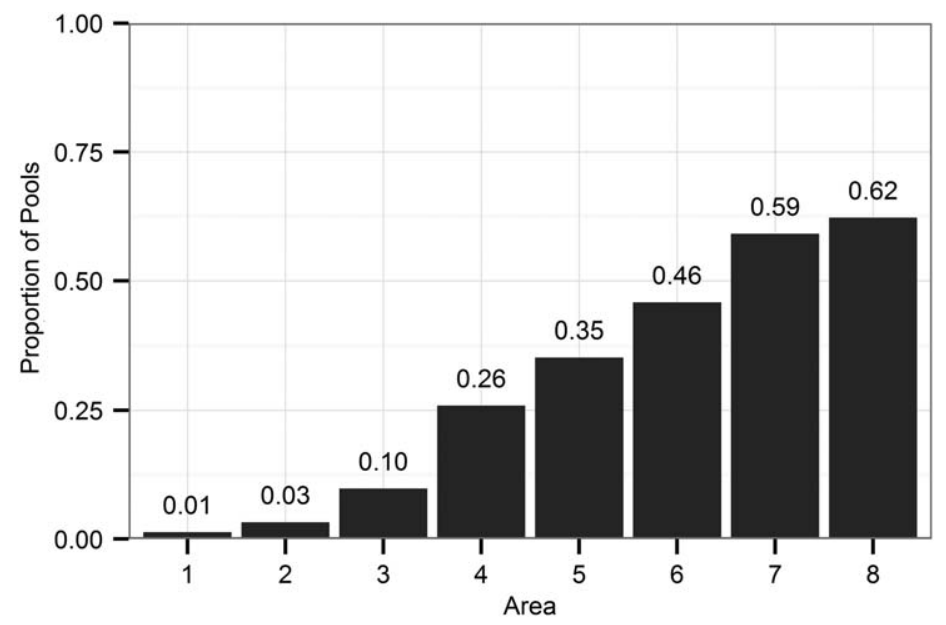

Fig. 4. Fraction of each working area occupied by unvegetated pools in 2010 (values above bar). Pools represent vegetation die-off and do not include tidal channels. Working areas 1-8 correspond to increasing distances up the Blackwater River toward Lake Blackwater.

increasing distances above $100 \mathrm{~m}$ from the river. At later time steps (1981 and 2010 represented in Fig. 5 as blue dashed and green solid lines, respectively), more pools start to form closer to the river as the amount of pool pixels keeps increasing. In the most intact marshes along the spatial dieoff gradient in 2010 (Fig. 6, working area 1) almost no detectable pool pixels are present, and if any, there is no apparent spatial pattern. As we move upstream the river, pools appear first at distances further than $75 \mathrm{~m}$ from the river and continue to increase in number and toward the river, so that from area 3 onward (the dashed line in Fig. 6), similar patterns and developments arise as observed in the temporal analysis: in areas that are little affected by vegetation die-off, the pool percentage increases almost linearly with distance from the river, with the distance of first die-off decreasing at higher die-off percentages (e.g., from Fig. 5 area 4 , the distance to the river decreases). In the more degraded areas, however, there is a sharp increase in vegetation die-off 

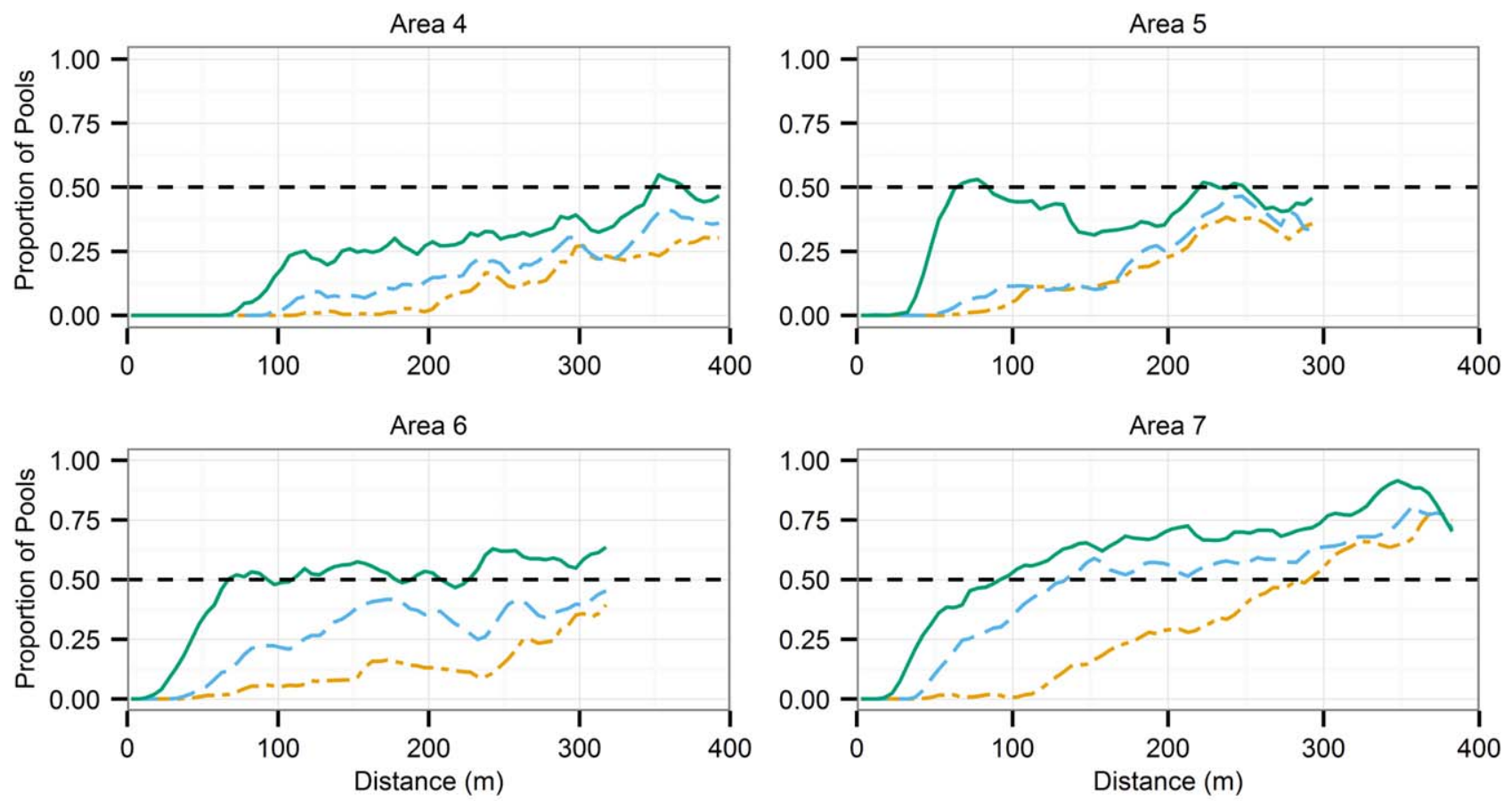

Year - - - 1938

$$
-1981-2010
$$

Fig. 5. Proportion of pool pixels with increasing distance to the Blackwater River for the different areas and time steps. The horizontal dashed line indicates $50 \%$. [Color figure can be viewed at wileyonlinelibrary.com]

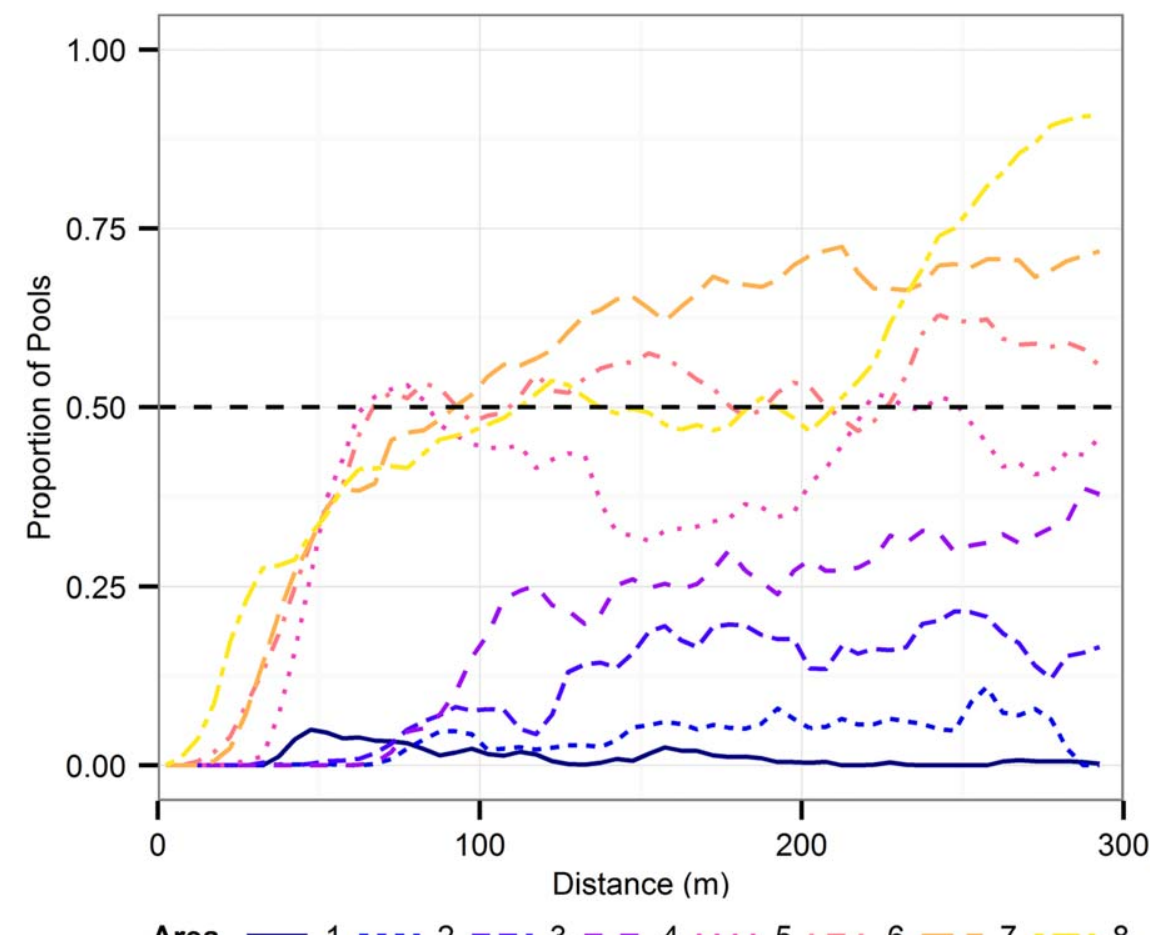

Fig. 6. Proportion of pool pixels with increasing distance to the Blackwater River for the different areas in 2010. The black horizontal dashed line indicates $50 \%$. [Color figure can be viewed at wileyonlinelibrary.com] 

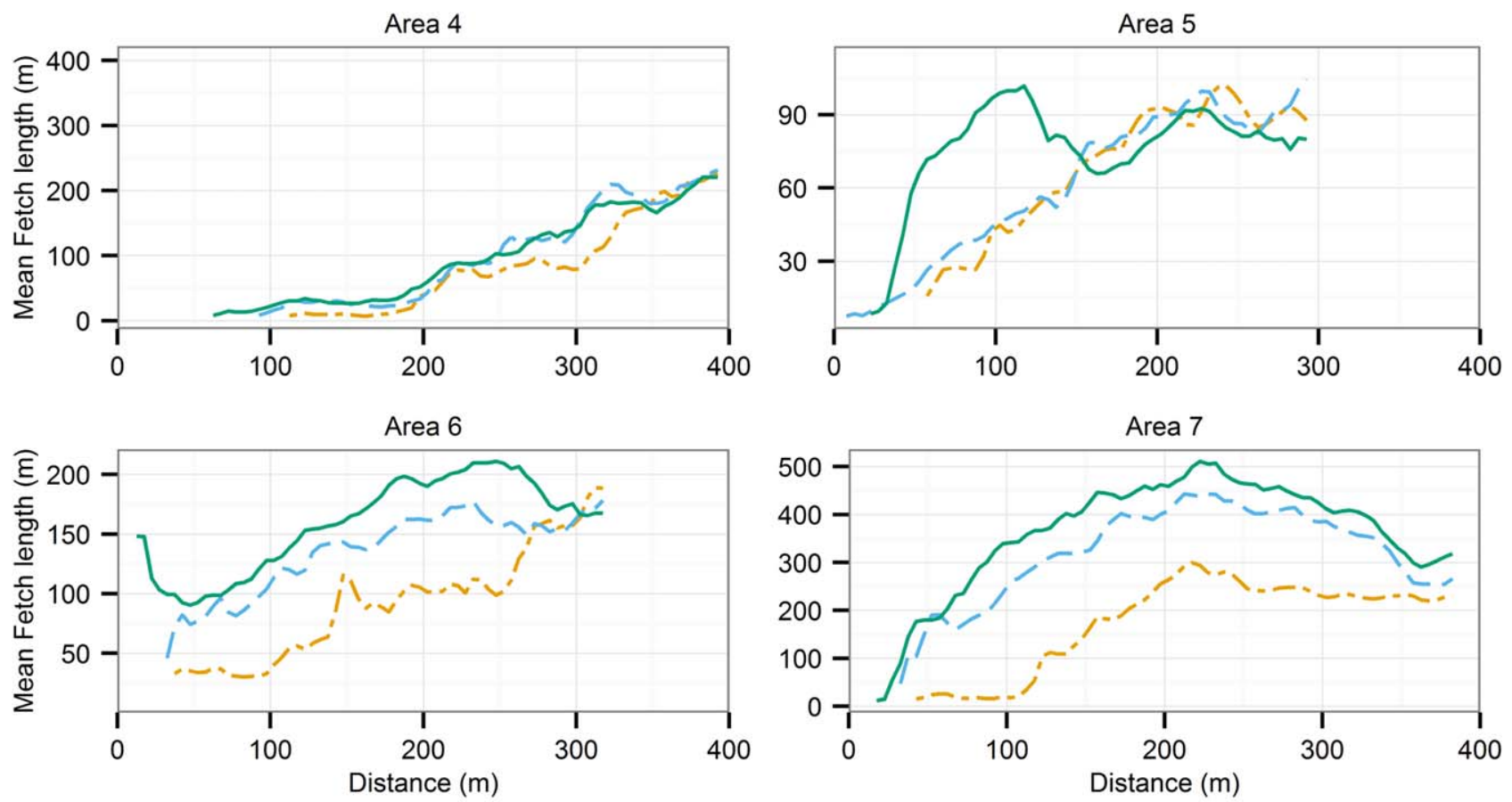

Year - - - 1938

1981

2010

Fig. 7. Temporal evolution of mean fetch length $(m)$, the average distance across pools measured along four line orientations, as a function of distance to the river for different areas. Note that the $Y$-axes have different scales. [Color figure can be viewed at wileyonlinelibrary.com]

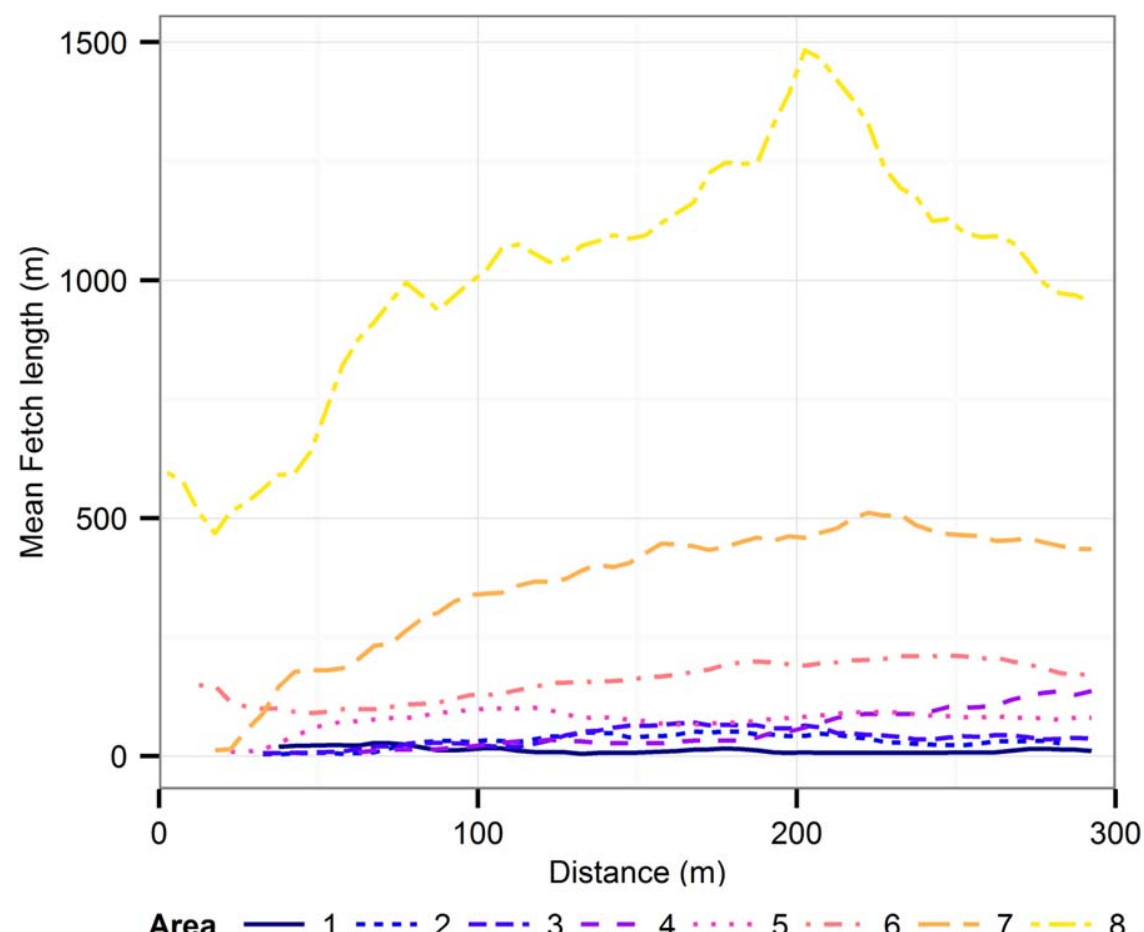

Fig. 8. Mean fetch length $(m)$, the average distance across pools measured along four line orientations, as function of distance to the river for the different areas along the spatial die-off gradient in 2010. [Color figure can be viewed at wileyonlinelibrary.com] 
with increasing distance from the river until about $50 \%$ is reached, and at higher distances it seems to fluctuate around the 50\% line. At the highest die-off percentages (areas 7 and $8)$, the percentage of pools continues to rise with increasing distance from the river. At all areas and time steps, there are no pools at distances $<30 \mathrm{~m}$ from the river.

\section{Relations between pool size and distance from channels}

The mean fetch length, a proxy for the size of the pools calculated as the average distance across pools along four line orientations, is visualized at different distances from the river in Figs. 7 and 8 . The fetches increase with distance from the river, meaning that bigger pools or open water areas occur with increasing distance from the river. No pools are visible very close to the river $(<30 \mathrm{~m})$, except for area 6 where a big pool expanded very close to the river in 2010, visible as high fetch length values at short distances (green solid line in Fig. 7, area 6). In time, there is a gradual increase in fetch length over the entire distance section (Fig. 7). In area 4 , there is not a big difference between the time steps, but more upstream (areas 5-7) the changes are remarkable. The results along the spatial die-off gradient (Fig. 8) are consistent with the results of the temporal die-off development (Fig. 7).

\section{Discussion}

\section{Observed spatial and temporal patterns of vegetation die-off}

Vegetation die-off is a key process influencing the loss of tidal marshes, and quantitative descriptions of its spatiotemporal development are needed to help understand the eco-geomorphic feedbacks driving wetland submergence. To our knowledge, this is the first time that the spatio-temporal development of a complete gradient of vegetation die-off from small isolated pools to a totally degraded marsh has been quantified. Our observations reveal two key insights: (i) The extent of die-off increases with distance upriver and through time. (ii) Die-off is not randomly distributed across the marsh surface but begins as small pools far from the river. At these locations pools grow, while new small pools gradually emerge closer to the river. The most stable areas that are unaffected by vegetation die-off are mainly located close to the river.

Our results document an increase in the extent of unvegetated pools with distance up the Blackwater River, where pools represent approximately $1 \%$ of marsh area at Area 1 (Fishing Bay) and $62 \%$ of marsh area in area 8 (close to Lake Blackwater). Gradients in sediment availability and tidal range may explain this spatial gradient in die-off extent. In our study area, both Ganju et al. (2013) and Stevenson et al. (1985) postulate two processes explaining a gradient in sediment availability: (i) at the upstream end, there is no external source of sediment. The long distance from the nearest downstream source, Fishing Bay, may result in a decreasing sediment supply to places with an increasing upstream distance from the sediment source. So the further upstream, the less likely suspended sediment will reach these sites. (ii) Windgenerated wave erosion and resuspension at Lake Blackwater leads locally to high sediment concentrations during northwestern storms, but the same northwestern winds drive a meteorological ebb tide, transporting a lot of the material toward Fishing Bay through the river. The internal generated sediment is exported out of the system and leads to an unstable system in the upstream parts of the river (Ganju et al. 2013, 2015). A significant amount of the transported sediment from Lake Blackwater, however, might be deposited at the marsh surface close to the river banks (Ganju et al. 2013). A third (iii) possible explanation for the die-off gradient in our study area is the decrease of (spring) tidal amplitude at upstream sites along the Blackwater River, from over $1.0 \mathrm{~m}$ at the Fishing Bay to less than $0.2 \mathrm{~m}$ at the Blackwater lake (Ganju et al. 2013). As tidal amplitude decreases, we may expect that the elevation range at which marsh plants can grow squeezes (e.g., McKee and Patrick, 1988). It is expected that marshes with a larger tidal range and hence a larger elevation range suitable for marsh vegetation have a higher capacity to keep up with sea level rise (Kirwan and Guntenspergen 2010; Kirwan et al. 2010; D'Alpaos et al. 2011). However, these responses to different tidal ranges have not been shown within a single estuary, and field measurements (e.g., elevation measurements compared to the local tidal frame) need to confirm this hypothesis.

The main tidal channel is an important factor determining vegetation die-off. We observed that the marsh loss starts as small die-off areas in the inner marsh, at a distance of at least $75 \mathrm{~m}$ from the main tidal creek, and increases with distance from the Blackwater River (Figs. 4 and 5). At shorter distances, the marshes appear to be stable. This is also qualitatively described in other study areas: in coastal Louisiana, interior die-off "hot spots" start as isolated patches (Morton et al. 2003), and previous studies in the Blackwater marshes (Stevenson et al. 1985) and in a New England Marsh (Redfield 1972) describe the occurrence of interior ponds, the larger ones located relatively remote from the drainage creeks (Redfield 1972). Our observations might be explained by several mechanisms. First, the majority of suspended sediment is deposited close to main tidal channels so that interior marshes typically receive less sediment input (Reed et al. 1999; Leonard and Reed 2002; Temmerman et al. 2003; Moskalski and Sommerfield 2012). This might explain the higher stability of marsh zones close to tidal channels. Indeed, the average sediment deposition rates close to the river edges is $6 \mathrm{~mm} \mathrm{yr}^{-1}$ (Ganju et al. 2013), offsetting local relative sea level rise of $3.72 \mathrm{~mm} \mathrm{yr}^{-1}$ (NOAA station 8571892, http:// tidesandcurrents.noaa.gov/sltrends, 2/23/2016). These differences can have profound effects on biological feedback mechanisms. Higher elevations at the channel levees compared to the interior marshes support higher aboveground (Nyman et al. 2006; Langley et al. 2013) and belowground 


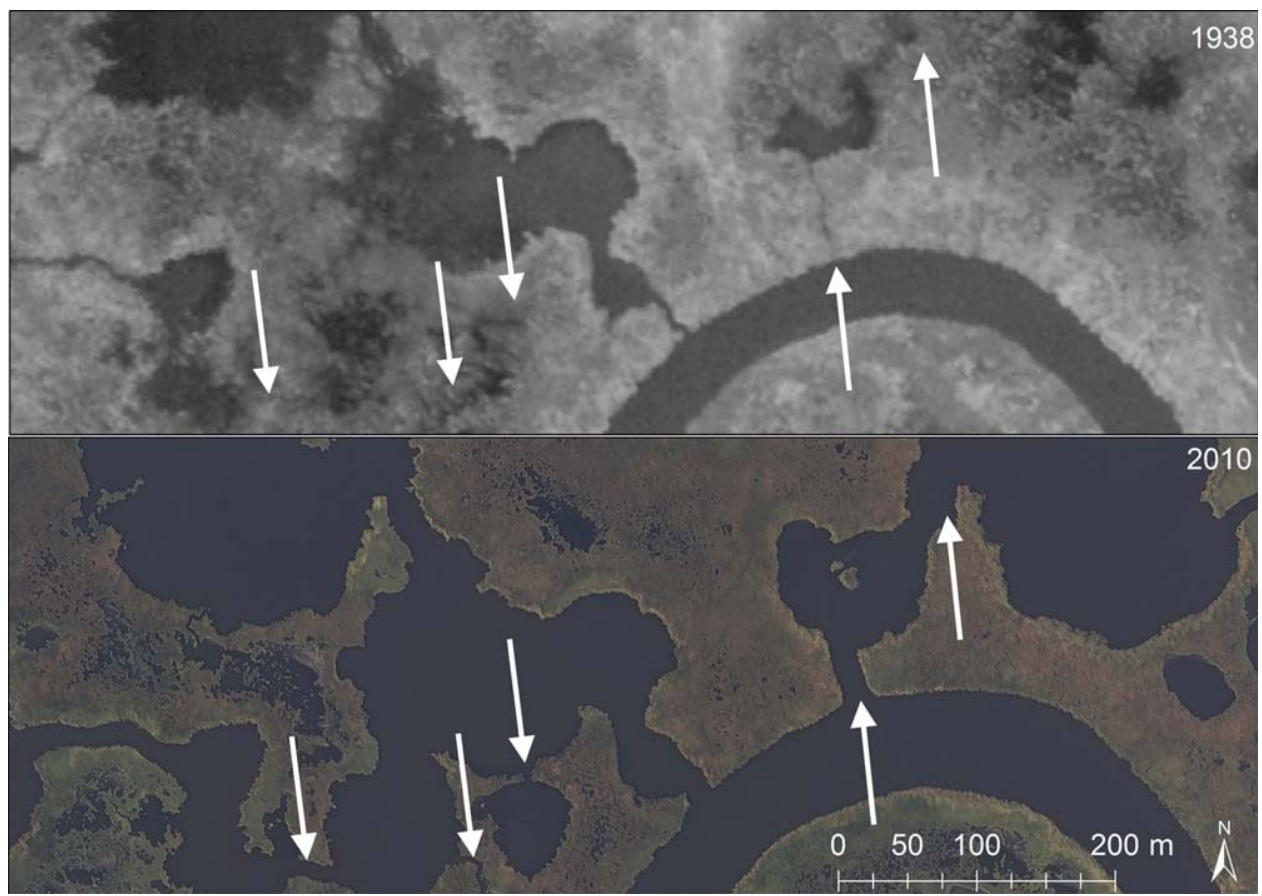

Fig. 9. Examples of increased connectivity between pools and the tidal channel network (white arrows) in 2010 (bottom) compared to 1938 (top) (location: working area 6, see Fig. 1b). Dark areas represent channels or pools. [Color figure can be viewed at wileyonlinelibrary.com]

biomass (Kirwan and Guntenspergen 2012; Langley et al. 2013). Also productivity (Morris et al. 2002) and growth rate (Mudd et al. 2009) may be enhanced by the recent sea level rise in high elevated marsh portions. As a consequence, we may expect more accretion by aboveground and belowground organic matter production and more soil-stabilizing roots close to the river, stabilizing these areas. The accretion deficit (i.e., accretion rates being lower than rate of relative sea level rise) at the interior marsh, conversely, might lead to elevations where biomass production is reduced (Morris et al. 2002; Nyman et al. 2006; Kirwan et al. 2010; Langley et al. 2013) and hence both organic matter accumulation and vegetation-induced suspended sediment deposition will decrease. This may result in an enhanced lowering within the tidal frame, up to the point where vegetation will dieoff. The vegetation die-off far from the river might also be initiated by insufficient subsurface drainage of the wetland soil, as vegetation die-off was found to start far from tidal channels that act as drainage channels for soil subsurface flow and consequent soil aeration (Ursino et al. 2004). It is known that insufficient drainage can cause waterlogging and salinity stress that kill vegetation (Redfield 1972; Wilson et al. 2009).

\section{Possible implications for bio-geomorphic response of marshes}

The pattern of development of marsh die-off is expected to have important implications for the bio-geomorphic response of marshes, as spatial vegetation patterns are known to be important in determining the spatial distribution of hydrodynamic and erosional forces (Temmerman et al. 2007; Vandenbruwaene et al. 2011b; Bouma et al. 2013). At initial vegetation die-off, small and medium sized pools far from the tidal channels are expected to have limited hydrodynamic feedback effects, as tidal flows are slowed down by friction of the surrounding vegetation, and fetches are too small to create significant waves (Mariotti and Fagherazzi 2013). This is shown in our analysis, where the pools start small, far from the main tidal channels and gradually expand.

As pools further expand, it can be expected that they become more vulnerable to wave erosion (Stevenson et al., 1985; Ganju et al., 2013). Once a critical threshold fetch length is passed, irreversible wave-induced marsh erosion will likely take place (Mariotti and Fagherazzi 2013). This has already been started in Blackwater Lake, where erosion of the lake shoreline takes place (Ganju et al., 2013).

At some locations, there might be another physical feedback mechanism that enhances erosion. When pools expand, they connect to the tidal creek network. This is observed in our study area (see Fig. 9) and is also observed in other marsh areas by a.o. Kearney et al. (1988), Perillo and Iribarne (2003), Van Huissteden and Van De Plassche (1998), Wilson et al. $(2009,2014)$. When the pools are hydraulically connected to the tidal channel system, the flow velocities in the pools during tidal flooding and drainage are expected to become higher and the pool bottom might become more susceptible to 
erosion, because pool substrates are generally loose muddy sediments with a high water content (Stevenson et al. 1985; van Huissteden and van de Plassche 1998; Wilson et al. 2010). Also Day et al. (2011) noted that the degraded, liquefied soil material in inner-marsh pools might be exported by low energy waves and currents. It should be noted that the erosional effect of tidal connections applies to the studied low-energy micro-tidal river system. In other areas with higher tidal range or energy, a new tidal connection might be a source of sediment and can lead to high rates of sediment accretion and pool infilling, especially after revegetation (Redfield 1972; Perillo et al. 1996; Millette et al. 2010; Wilson et al. 2010, 2014). The above-discussed feedback mechanism between vegetation die-off and erosion may imply that there might be a vegetation die-off threshold after which irreversible erosion by waves and possibly by tidal currents will take place.

\section{Evidence for a chronosequence along the main tidal channel}

We observed a similar spatial development of vegetation die-off from moderately to highly degraded marshes over a time series from 1938 to 2010 and along a contemporary spatial gradient along the Blackwater River. Both developments show a steady increase in pool cover (Figs. 3 and 4) and, in particular, the distances at which pools form (Figs. 5 and 6) and enlarge (Figs. 7 and 8 ) are very similar along the temporal and spatial gradient. This finding suggest that the present-day spatial gradient might be used as a chronosequence, a spacefor-time substitution often used by ecologists and geomorphologists to study long-term temporal evolution and development of landscapes (Conn and Day 1997; Olff et al. 1997; van de Koppel et al. 2005). In other words, the spatial gradient of vegetation die-off along the Blackwater River offers a unique opportunity to study the processes that lead to progressive marsh die-off, such as the effect of spatial patterns and feedbacks of vegetation die-off over time. The chronosequence also implies that, if marsh vegetation die-off continues, we may expect the same temporal development as observed along the present-day spatial gradient.

\section{Conclusion}

We found that the spatial distribution of vegetation dieoff (the location of pools) in our study area is not a random pattern. Initial vegetation die-off starts at a distance of more than $75 \mathrm{~m}$ from tidal channels. As vegetation die-off continues, pools expand and new pools emerge closer and closer to the tidal channels. As a result, the larger pools will be situated at distant locations from the tidal channels and pools are smaller closer to the channels. These developments are observed in time, as well as on a spatial gradient, indicating that the present-day spatial gradient can be considered a chronosequence. Potential processes explaining our observed patterns are differential sedimentation and soil drainage between marsh locations at different distances from the tidal channels, with marshes adjacent to channels having higher sedimentation rates, better soil drainage and hence better plant growth conditions and stronger soils than inner marsh locations farther away from channels.

Based on our observations, we expect that for a certain degree of vegetation die-off, bio-geomorphic feedback mechanisms will enhance marsh soil erosion, resulting in even more marsh loss. Hence, our study highlights the importance of studying the spatial development of vegetation dieoff and the effect on bio-geomorphic feedback mechanisms. However, further studies are necessary to gain more knowledge about a possible shift in sedimentation and erosion rates with increasing vegetation die-off to prevent further marsh loss on a large scale.

\section{References}

Alber, M., E. M. Swenson, S. C. Adamowicz, and I. A. Mendelssohn. 2008. Salt Marsh Dieback: An overview of recent events in the US. Estuar. Coast. Shelf Sci. 80: 1-11. doi:10.1016/j.ecss.2008.08.009

Allen, J. R. L. 1990. Salt-marsh growth and stratification: A numerical model with special reference to the Severn Estuary, southwest Britain. Mar. Geol. 95: 77-96. doi: 10.1016/0025-3227(90)90042-I

Barbier, E. B., S. D. Hacker, C. Kennedy, E. W. Koch, A. C. Stier, and B. R. Silliman. 2011. The value of estuarine and coastal ecosystem services. Ecol. Monogr. 81: 169-193. doi:10.1890/10-1510.1

Baustian, J. J., I. A. Mendelssohn, and M. W. Hester. 2012. Vegetation's importance in regulating surface elevation in a coastal salt marsh facing elevated rates of sea level rise. Glob. Chang. Biol. 18: 3377-3382. doi:10.1111/j.13652486.2012.02792.x

Boston, K. G. 1983. The development of salt pans on tidal marshes, with particular reference to south-eastern Australia. J. Biogeogr. 10: 1-10. doi:10.2307/2844578

Bouma, T. J., and others. 2013. Organism traits determine the strength of scale-dependent bio-geomorphic feedbacks: A flume study on three intertidal plant species. Geomorphology. 180-181: 57-65. doi:10.1016/j.geomorph.2012.09.005

Cahoon, D. R., G. R. Guntenspergen, and S. Baird. 2010. Do Annual Prescribed Fires Enhance or Slow the Loss of Coastal Marsh Habitat at Blackwater National Wildlife Refuge? Final Report to Joint Fire Science Program Project Number 06-2-1-35. Available at http://www.firescience.gov/ projects/06-2-1-35/project/06-2-1-35_blackwater_burn_final_ report_mar_31_2010.pdf.

Carniello, L., A. Defina, and L. D'Alpaos. 2009. Morphological evolution of the Venice lagoon: Evidence from the past and trend for the future. J. Geophys. Res. Earth Surf. 114: 1: 10. doi:10.1029/2008JF001157 
Conn, C. E., and F. P. Day. 1997. Root decomposition across a barrier island chronosequence: Litter quality and environmental controls. Plant Soil 195: 351-364. doi:10.1023/ A:1004214216889

D'Alpaos, A., S. Lanzoni, M. Marani, and A. Rinaldo. 2007. Landscape evolution in tidal embayments: Modeling the interplay of erosion, sedimentation, and vegetation dynamics. J. Geophys. Res. Earth Surf. 112: 1-17. doi:10.1029/2006JF000537

D'Alpaos, A., S. M. Mudd, and L. Carniello. 2011. Dynamic response of marshes to perturbations in suspended sediment concentrations and rates of relative sea level rise. J. Geophys. Res. Earth Surf. 116: 1-13. doi:10.1029/2011 JF002093

Day, J. W., L. D. Britsch, S. R. Hawes, G. P. Shaffer, D. J. Reed, and D. R. Cahoon. 2000. Pattern and process of land loss in the Mississippi Delta: A spatial and temporal analysis of wetland habitat change. Estuaries 23: 425. doi: $10.2307 / 1353136$

Day, J. W., G. P. Kemp, D. J. Reed, D. R. Cahoon, R. M. Boumans, J. M. Suhayda, and R. Gambrell. 2011. Vegetation death and rapid loss of surface elevation in two contrasting Mississippi delta salt marshes: The role of sedimentation, autocompaction and sea-level rise. Ecol. Eng. 37: 229-240. doi:10.1016/j.ecoleng.2010.11.021

DeLaune, R. D., and S. R. Pezeshki. 1994. The Influence of Subsidence and Saltwater Intrusion on Coastal Marsh Stability:Louisiana Gulf Coast, U.S.A. J. Coast. Res. 77-89. http://www.jstor.org/stable/25735591.

DeLaune, R. D., J. A. Nyman, and W. H. Patrick. 1994. Peat collapse, ponding and wetland loss in a rapidly submerging coastal marsh. J. Coast. Res. 10: 1021-1030. http:// www.jstor.org/stable/4298293.

Fagherazzi, S., L. Carniello, L. D'Alpaos, and A. Defina. 2006. Critical bifurcation of shallow microtidal landforms in tidal flats and salt marshes. Proc. Natl. Acad. Sci. USA 103: 8337-8341. doi:10.1073/pnas.0508379103

Fagherazzi, S., and others. 2012. Numerical models of salt marsh evolution: Ecological, geomorphic, and climatic factors. Rev. Geophys. 50: RG1002. doi:10.1029/2011RG000359

French, J. R. 1993. Numerical simulation of vertical marsh growth and adjustment to accelerated sea-level rise, North Norfolk, U.K. Earth Surf. Process. Landforms 18: 63-81. doi:10.1002/esp.3290180105

Ganju, N. K., N. J. Nidzieko, and M. L. Kirwan. 2013. Inferring tidal wetland stability from channel sediment fluxes: Observations and a conceptual model. J. Geophys. Res. Earth Surf. 118: 2045-2058. doi:10.1002/jgrf.20143

Ganju, N. K., M. L. Kirwan, P. J. Dickhudt, G. R. Guntenspergen, D. R. Cahoon, and K. D. Kroeger. 2015. Sediment transport-based metrics of wetland stability. Geophys. Res. Lett. 42: 7992-8000. doi:10.1002/2015GL065980

Holdredge, C., M. D. Bertness, and A. H. Altieri. 2009. Role of crab herbivory in die-off of New England Salt Marshes. Conserv. Biol. 23: 672-679. doi:10.1111/j.1523-1739.2008.01137.x
Kearney, M. S., R. E. Grace, and J. C. Stevenson. 1988. Marsh Loss in Nanticoke Estuary, Chesapeake Bay. Geogr. Rev. 78: 205. doi:10.2307/214178

Kearney, M. S., A. S. Rogers, J. R. G. Townshend, E. Rizzo, D. Stutzer, J. C. Stevenson, and K. Sundborg. 2002. Landsat imagery shows decline of coastal marshes in Chesapeake and Delaware Bays. Eos, Trans. Am. Geophys. Union. 83: 173-178. doi:10.1029/2002EO000112

Kéfi, S., and others. 2014. Early warning signals of ecological transitions: Methods for spatial patterns. PLoS One. 9: e92097. doi:10.1371/journal.pone.0092097

Kendrot, S. R. 2011. Restoration through eradication : Protecting Chesapeake Bay marshlands from invasive nutria (Myocastor coypus), p. 313-319. Island Invasives: Eradication and Management. Proceedings of the International Conference on Island Invasives.

Kirwan, M. L., and A. B. Murray. 2007. A coupled geomorphic and ecological model of tidal marsh evolution. Proc. Natl. Acad. Sci. USA 104: 6118-6122. doi:10.1073/pnas. 0700958104

Kirwan, M. L., A. B. Murray, and W. S. Boyd. 2008. Temporary vegetation disturbance as an explanation for permanent loss of tidal wetlands. Geophys. Res. Lett. 35: L05403. doi:10.1029/2007GL032681

Kirwan, M. L., and G. R. Guntenspergen. 2010. Influence of tidal range on the stability of coastal marshland. J. Geophys. Res. 115: F02009. doi:10.1029/2009JF001400

Kirwan, M. L., G. R. Guntenspergen, A. D'Alpaos, J. T. Morris, S. M. Mudd, and S. Temmerman. 2010. Limits on the adaptability of coastal marshes to rising sea level. Geophys. Res. Lett. 37:L23401. doi:10.1029/2010GL045489

Kirwan, M. L., and G. R. Guntenspergen. 2012. Feedbacks between inundation, root production, and shoot growth in a rapidly submerging brackish marsh. J. Ecol. 100: 764-770. doi:10.1111/j.1365-2745.2012.01957.x

Kirwan, M. L., and J. P. Megonigal. 2013. Tidal wetland stability in the face of human impacts and sea-level rise. Nature 504: 53-60. doi:10.1038/nature12856

Kirwan, M. L., and G. R. Guntenspergen. 2015. Response of plant productivity to experimental flooding in a stable and a submerging marsh. Ecosystems 18: 903-913. doi: 10.1007/s10021-015-9870-0

Kirwan, M. L., S. Temmerman, E. E. Skeehan, G. R. Guntenspergen, and S. Fagherazzi. 2016. Overestimation of marsh vulnerability to sea level rise. Nat. Clim. Chang. 6: 253-260. doi:10.1038/nclimate2909

Langley, J. A., T. J. Mozdzer, K. A. Shepard, S. B. Hagerty, and J. P. Megonigal. 2013. Tidal marsh plant responses to elevated CO 2, nitrogen fertilization, and sea level rise. Glob. Chang. Biol. 19: 1495-1503. doi:10.1111/ gcb. 12147

Leonard, L. A., and D. J. Reed. 2002. Hydrodynamics and sediment transport through tidal marsh canopies. J. Coast. Res. 459-36. 469.doi:10.1016/j.ecss.2006.05.004 
Leonard, L. A., and A. L. Croft. 2006. The effect of standing biomass on flow velocity and turbulence in Spartina alterniflora canopies. Estuar. Coast. Shelf Sci. 69: 325-336. doi:10.1016/j.ecss.2006.05.004

Marani, M., A. D'Alpaos, S. Lanzoni, L. Carniello, and A. Rinaldo. 2010. The importance of being coupled: Stable states and catastrophic shifts in tidal biomorphodynamics. J. Geophys. Res. Earth Surf. 115: 1-15. doi:10.1029/ 2009JF001600

Mariotti, G., and S. Fagherazzi. 2013. Critical width of tidal flats triggers marsh collapse in the absence of sea-level rise. Proc. Natl. Acad. Sci. USA 110: 5353-5356. doi: 10.1073/pnas.1219600110

Mariotti, G., and J. Carr. 2014. Dual role of salt marsh retreat: Long-term loss and short-term resilience. Water Resour. Res. 50: 2963-2974. doi:10.1002/2013WR014676

McGarigal, K., S. A. Cushman, and E. Ene. 2012. FRAGSTATS v4: Spatial Pattern Analysis Program for Categorical and Continuous Maps. Computer Software Program Produced by the Authors at the University of Massachusetts, Amherst. Available from http://www.umass.edu/landeco/ research/fragstats/fragstats.html.

McKee, K. L., and W. H. Patrick. 1988. The Relationship of Smooth Cordgrass (Spartina alterniflora) to Tidal Datums: A Review. Estuaries 11: 143-151. doi:10.2307/1351966

Mendelssohn, I. A., and K. L. McKee. 1988. Spartina alterniflora die-back in Louisiana: Time-course investigation of soil waterlogging effects. J. Ecol. 76: 509. doi:10.2307/2260609

Millette, T. L., B. A. Argow, E. Marcano, C. Hayward, C. S. Hopkinson, and V. Valentine. 2010. Integration of multitemporal multispectral remote sensing with LIDAR and GIS. J. Coast. Res. 265: 809-816. doi:10.2112/JCOASTRESD-09-00101.1

Möller, I., and others. 2014. Wave attenuation over coastal salt marshes under storm surge conditions. Nat. Geosci. 7: 727-731. doi:10.1038/ngeo2251

Morris, J. T., P. V. Sundareshwar, C. T. Nietch, B. Kjerfve, and D. R. Cahoon. 2002. Responses of coastal wetlands to rising sea level. Ecology 83: 2869-2877. doi:10.1890/ 0012-9658(2002)083[2869:ROCWTR]2.0.CO;2

Morton, R. A., G. Tiling, and N. F. Ferina. 2003. Causes of hot-spot wetland loss in the Mississippi delta plain. Environ. Geosci. 10: 71-80. doi:10.1306/eg100202007

Moskalski, S. M., and C. K. Sommerfield. 2012. Suspended sediment deposition and trapping efficiency in a Delaware salt marsh. Geomorphology 139-140: 195-204. doi: 10.1016/j.geomorph.2011.10.018

Mudd, S. M., S. M. Howell, and J. T. Morris. 2009. Impact of dynamic feedbacks between sedimentation, sea-level rise, and biomass production on near-surface marsh stratigraphy and carbon accumulation. Estuar. Coast. Shelf Sci. 82: 377-389. doi:10.1016/j.ecss.2009.01.028

Mudd, S. M., A. D'Alpaos, and J. T. Morris. 2010. How does vegetation affect sedimentation on tidal marshes?
Investigating particle capture and hydrodynamic controls on biologically mediated sedimentation. J. Geophys. Res. 115: F03029. doi:10.1029/2009JF001566

Nyman, J. A., R. D. DeLaune, H. H. Roberts, and W. H. Patrick. 1993. Relationship between vegetation and soil formation in a rapidly submerging coastal marsh. Mar. Ecol. Prog. Ser. 96: 269-279. doi:10.3354/meps096269

Nyman, J. A., R. J. Walters, R. D. DeLaune, and W. H. Patrick. 2006. Marsh vertical accretion via vegetative growth. Estuar. Coast. Shelf Sci. 69: 370-380. doi: 10.1016/j.ecss.2006.05.041

Olff, H., J. De Leeuw, J. P. Bakker, R. J. Platerink, and H. J. van Wijnen. 1997. Vegetation succession and herbivory in a salt marsh: Changes induced by sea level rise and silt deposition along an elevational gradient. J. Ecol. 85: 799. doi: $10.2307 / 2960603$

Penland, S., L. Wayne, D. Britsch, S. J. Williams, A. D. Beall, and V. Butterworth. 2000. Geomorphic Classification of Coastal Land Loss between 1932 and 1990 in the Mississippi River Delta Plain, Southeastern Louisiana. USGS Open File Report 00-417, available at http://pubs.usgs. gov/of/2000/of00-417/ofr00-417.pdf.

Perillo, G. M. E., M. D. Ripley, M. C. Piccolo, and K. R. Dyer. 1996. The formation of tidal creeks in a Salt Marsh : New evidence from the Loyola Bay Salt Marsh, Rio Gallegos Estuary, Argentina. Mangroves Salt Marshes 1: 37-46. doi: 10.1023/A:1025942111382

Perillo, G. M. E., and O. O. Iribarne. 2003. Processes of tidal channel development in salt and freshwater marshes. Earth Surf. Process. Landforms 28: 1473-1482. doi:10.1002/esp.1018

Pethick, J. S. 1974. The Distribution of Salt Pans on Tidal Salt Marshes. J. Biogeogr. 1: 57-62. doi: 10.2307/3038068

Pethick, J. S. 1981. Long-term Accretion Rates on Tidal Salt Marshes. J. Sediment. Res. 51: 571-577. doi:10.1306/ 212F7CDE-2B24-11D7-8648000102C1865D

R Core Team. 2016. R: A Language and Environment for Statistical Computing, Vienna, Austria.

Redfield, A. C. 1972. Development of a New England Salt Marsh. Ecol. Monogr. 42: 201-237. doi:10.2307/1942263

Reed, D. J., T. Spencer, A. L. Murray, J. R. French, and L. Leonard. 1999. Marsh surface sediment deposition and the role of tidal creeks: Implications for created and managed coastal marshes. J. Coast. Conserv. 5: 81-90. doi: 10.1007/BF02802742

Russi, D., and others. 2013. The Economics of Ecosystems and Biodiversity (TEEB) for Water and Wetlands. IEEP, London and Brussels; Ramsar Secretariat, Gland.

Scott, M., L. McDermott, E. Silva, and E. Watson. 2009. Project report: Digital Spatial Data Capture of Marsh Extent in Blackwater National Wildlife Refuge, 1938 and 2006. Eastern Shore Regional GIS Cooperative, Salisbury University.

Silliman, B. R. 2005. Drought, snails, and large-scale die-off of Southern U.S. Salt Marshes. Science (80-.) 310: 18031806. doi:10.1126/science.1118229 
Smith, S. M. 2009. Multi-decadal changes in Salt Marshes of Cape Cod, MA: Photographic analyses of vegetation loss, species shifts, and geomorphic change. Northeast. Nat. 16: 183-208. doi:10.1656/045.016.0203

Stevenson, J. C., M. S. Kearney, and E. C. Pendleton. 1985. Sedimentation and erosion in a Chesapeake Bay brackish marsh system. Mar. Geol. 67: 213-235. doi:10.1016/00253227(85)90093-3

Temmerman, S., G. Govers, S. Wartel, and P. Meire. 2003. Spatial and temporal factors controlling short-term sedimentation in a salt and freshwater tidal marsh, scheldt estuary, Belgium, SW Netherlands. Earth Surf. Process. Landforms 28: 739-755. doi:10.1002/esp.495

Temmerman, S., T. J. Bouma, J. van de Koppel, D. van der Wal, M. B. De Vries, and P. M. J. Herman. 2007. Vegetation causes channel erosion in a tidal landscape. Geology 35: 631-634. doi:10.1130/G23502A.1

Temmerman, S., P. Moonen, J. Schoelynck, G. Govers, and T. J. Bouma. 2012a. Impact of vegetation die-off on spatial flow patterns over a tidal marsh. Geophys. Res. Lett. 39: 1-5. doi:10.1029/2011GL050502

Temmerman, S., M. B. De Vries, and T. J. Bouma. 2012b. Coastal marsh die-off and reduced attenuation of coastal floods: A model analysis. Glob. Planet. Chang. 92-93: 267-274. doi:10.1016/j.gloplacha.2012.06.001

Temmerman, S., P. Meire, T. J. Bouma, P. M. J. Herman, T. Ysebaert, and H. J. De Vriend. 2013. Ecosystem-based coastal defence in the face of global change. Nature 504: 79-83. doi:10.1038/nature12859

Temmerman, S., and M. L. Kirwan. 2015. Building land with a rising sea. Science (80-.) 349: 588-589. doi:10.1126/ science.aac8312

Ursino, N., S. Silvestri, and M. Marani. 2004. Subsurface flow and vegetation patterns in tidal environments. Water Resour. Res. 40: W05115. doi:10.1029/2003WR002702

Vandenbruwaene, W., T. Maris, T. J. S. Cox, D. R. Cahoon, P. Meire, and S. Temmerman. 2011a. Sedimentation and response to sea-level rise of a restored marsh with reduced tidal exchange: Comparison with a natural tidal marsh. Geomorphology 130: 115-126. doi:10.1016/j.geomorph. 2011.03.004

Vandenbruwaene, and others. 2011b. Flow interaction with dynamic vegetation patches: Implications for biogeomorphic evolution of a tidal landscape. J. Geophys. Res. Earth Surf. 116: 1-13. doi:10.1029/2010JF001788

van de Koppel, J., D. Van der Wal, J. P. Bakker, and P. M. J. Herman. 2005. Self-Organization and Vegetation Collapse in Salt Marsh Ecosystems. Am. Nat. 165: E1-E12. doi: $10.1086 / 426602$

van Huissteden, J., and O. van de Plassche. 1998. Sulphate reduction as a geomorphological agent in tidal marshes ("Great Marshes" at Barnstable, Cape Cod, USA). Earth Surf.
Process. Landforms 23: 223-236. http://onlinelibrary.wiley. com/doi/10.1002/(SICI)1096-9837(199803)23:3\%3C223::AIDESP843\%3E3.0.CO;2-I/abstract

Wang, D. P., and A. J. Elliott. 1978. Non-tidal variability in the Chesapeake Bay and Potomac River: Evidence for non-local forcing. J. Phys. Oceanogr. 8: 225-232. doi: 10.1175/1520-0485(1978)008<0225:NTVITC > 2.0.CO;2

Wang, C., and S. Temmerman. 2013. Does biogeomorphic feedback lead to abrupt shifts between alternative landscape states?: An empirical study on intertidal flats and marshes. J. Geophys. Res. Earth Surf. 118: 229-240. doi: 10.1029/2012JF002474

Wells, J. T., and J. M. Coleman. 1987. Wetland loss and the subdelta life cycle. Estuar. Coast. Shelf Sci. 25: 111-125. doi:10.1016/0272-7714(87)90029-1

Wilson, K. R., J. T. Kelley, A. Croitoru, M. Dionne, D. F. Belknap, and R. Steneck. 2009. Stratigraphic and ecophysical characterizations of salt pools: Dynamic landforms of the webhannet salt marsh, wells, ME, USA. Estuaries Coasts 32: 855-870. doi:10.1007/s12237-009-9203-7

Wilson, K. R., J. T. Kelley, B. R. Tanner, and D. F. Belknap. 2010. Probing the Origins and Stratigraphic Signature of Salt Pools from North-Temperate Marshes in Maine, U.S.A. J. Coast. Res. 26: 1007-1026. doi:10.2112/ JCOASTRES-D-10-00007.1

Wilson, C. A., Z. J. Hughes, D. M. FitzGerald, C. S. Hopkinson, V. Valentine, and A. S. Kolker. 2014. Saltmarsh pool and tidal creek morphodynamics: Dynamic equilibrium of northern latitude saltmarshes? Geomorphology 213: 99-115. doi:10.1016/j.geomorph.2014.01.002

Yapp, R. H., D. Johns, and O. T. Jones. 1917. The Salt Marshes of the Dovey Estuary. J. Ecol. 5: 65. doi:10.2307/ 2255644

\section{Acknowledgments}

This project was financed by an UA-BOF DOCPRO grant (to L.S. and S.T.), the Research Foundation Flanders (FWO, PhD grant L.S., 11 S9614N, travel grants L.S. V428214N and S.T. K217414N), by the U.S. Geological Survey, Climate and Land-Use Research and Development Program (G.G.), by NSF GLD 1529245, NSF SEES 1426981, NSF LTER 1237733 (M.K.). We would like to thank the managers and biologists of the Blackwater National Wildlife Refuge for their assistance and valuable comments; and P. Brennand (USGS) for indispensable field assistance. Any use of trade, product, or firm names is for descriptive purposes only and does not imply endorsement by the U.S. Government.

\section{Conflict of Interest}

None declared.

Submitted 24 February 2016 Revised 4 July 2016 Accepted 7 July 2016

Associate editor: Luiz Drude de Lacerda 